\title{
Pattern of Thyroid Dysfunction in Women with Menstrual Disorders
}

\author{
Saroj Khatiwada ${ }^{*}$, Sharad Gautam² ${ }^{2}$ Rajendra KC ${ }^{1}$, Shruti Singh ${ }^{3}$, Shrijana Shrestha ${ }^{4}$, \\ Punam Jha ${ }^{4}$, Nirmal Baral ${ }^{4}$, Madhab Lamsal ${ }^{4}$
}

\begin{abstract}
Affiliations:
'Department of Biochemistry, Modern Technical College, Sanepa, Lalitpur, Nepal.

${ }^{2}$ Department of Biochemistry, School of Medical Sciences, Kathmandu University, Dhulikhel, Nepal.

${ }^{3}$ Department of Biochemistry, KIST Medical College and Teaching Hospital, Lalitpur, Nepal.

${ }^{4}$ Department of Biochemistry, B. P. Koirala Institute of Health Sciences, Dharan, Nepal.
\end{abstract}

Correspondence to:

Mr. Saroj Khatiwada

Lecturer

Department of Biochemistry

Modern Technical College

Sanepa, Lalitpur, Nepal.

Email: khatiwadasaroj22@gmail.com

How to cite this article:

Khatiwada S, Gautam S, KC R, Singh S, Shrestha S, Jha P, Baral N, Lamsal M. Pattern of Thyroid Dysfunction in Women with Menstrual Disorders. Ann. Clin. Chem. Lab. Med. 2016:2(1);3-6

DOI: http://dx.doi.org/10.3126/acclm.v2i1.14195

(C) 2016 Nepalese Association for Clinical Chemistry

\section{(c) (1) (2)}

This work is licensed under a Creative Commons

Attribution-ShareAlike 4.0 International License.

\section{Abstract \\ BACKGROUND}

Thyroid disorders are among the commonest endocrine disorders worldwide. Thyroid dysfunction can interfere in multiple metabolic and physiological processes including menstrual cycle. This study was conducted to find pattern of thyroid dysfunction among women with menstrual disorders.

\section{METHODS}

Two hundred thirty three females with menstrual disorders were screened for thyroid dysfunction. Thyroid function was assessed by measuring serum free triiodothyronine (T3), free thyroxine (T4) and thyroid stimulating hormone (TSH) levels.

\section{RESULTS}

The mean age of study patients was $25.7 \pm 6.8$ years. The most common menstrual disorder observed was irregular cycle $(72.5 \%, \mathrm{n}=169)$ followed by amenorrhea $(21.9 \%, \mathrm{n}=51)$ and menorrhagia $(5.6 \%$, $\mathrm{n}=13)$. Most of the patients were in the age group 1524 years $(51.1 \%, \mathrm{n}=119)$, followed by $25-34$ years $(36.1 \%, \mathrm{n}=84)$ and $35-45$ years $(12.9 \%, \mathrm{n}=30)$. Mean level of free T3 and T4 was $2.91 \pm 1.05 \mathrm{pg} / \mathrm{ml}$, $1.42 \pm 0.57 \mathrm{ng} / \mathrm{dl}$ respectively. Median TSH was 2.0 $\mathrm{mIU} / \mathrm{L}$ (IQR, 1.0-4.0). Thyroid dysfunction was seen in $25.8 \% \quad(\mathrm{n}=60)$ women. Most common thyroid dysfunction was subclinical hypothyroidism (14.2\%, $\mathrm{n}=33)$ followed by subclinical hyperthyroidism (6.9\%, $\mathrm{n}=16)$, overt hyperthyroidism $(3 \%, \mathrm{n}=7)$ and overt hypothyroidism $(1.7 \%, \mathrm{n}=4)$.

\section{CONCLUSIONS}

The study finds thyroid dysfunction especially subclinical hypothyroidism to be common among women with menstrual disorders. Thus, it may be beneficial to screen menstrual disorder patients for thyroid function especially to rule out thyroid disorder as potential etiological agent for menstrual disturbance.

KEYWORDS: Menstrual disorder, Thyroid dysfunction 


\section{Introduction}

Menstrual problems account for much of the morbidity, affecting one in every five women during their life span [1]. Prevalence of menstrual morbidity in developing countries is comparable to that observed in developed countries and menstrual dysfunction represents a problem for women in developing countries. In developing countries, abnormal uterine bleeding appears to affect about $5-15 \%$ of women of reproductive age and probably a higher percent of women in older age groups. Others menstrual disorders include amenorrhea, dysmenorrhea etc. [2].

Thyroid disorders are among the commonest endocrine disorders worldwide with females having higher dysfunction rate than males [3, 4]. Thyroid dysfunctions interfere with numerous aspects of reproduction and pregnancy and an association of hyperthyroidism or hypothyroidism with menstrual disturbance, anovulatory cycles, decreased fecundity and increased morbidity during pregnancy has been observed [5]. Thyroid dysfunction may have profound effects on the female reproductive system and thus women with thyroid dysfunction often have menstrual irregularities, infertility and increased morbidity during pregnancy [6].

Studies have reported thyroid dysfunction to be common among patients with diabetes mellitus, metabolic syndrome and kidney diseases in Nepal $[4,7]$. There is however little information about thyroid function status among females with menstrual disorders, and thus the importance of thyroid function test in such patients is unknown. In the light of inadequate information about thyroid function status in Nepalese women with menstrual disorders, we sought to find the pattern of thyroid dysfunction in Nepalese women with menstrual disorders by analyzing the retrospective data of women with menstrual disorders attending thyroid laboratory of B P Koirala Institute of Health Sciences, Dharan, Nepal. The study would be helpful in determining the burden of thyroid dysfunction in women with menstrual disorders and may help for clinical management of such women.

\section{Methods}

A retrospective one year (2012-2013) data of Nepalese women with menstrual disorders aged 15-45 years was analyzed for finding the pattern of thyroid dysfunction in such patients. All the patients in the reproductive age group (15-45 years) presenting with menstrual problems were searched for their thyroid status by considering serum free triiodothyronine (T3), free thyroxine (T4) and thyroid stimulating hormone (TSH) level. Exclusion criteria were women taking antithyroid drugs and women with known thyroid disorders. After screening, 233 women were identified to be suitable for the study. Ethical clearance was taken from institutional ethical committee.

Each patient age, type of menstrual disorders and thyroid hormones level were noted. Thyroid hormones were estimated by ELISA technique using kits from HUMAN diagnostics. The fT3 and fT4 estimation were based on the principle of competitive ELISA. TSH estimation was based on the principle of sandwich ELISA. Patients were divided into three groups on the basis of menstrual disorders present; first group with irregular cycle and included oligomenorrhea and polymenorrhea, second group with amenorrhea and third group with menorrhagia. The normal range for thyroid hormones; fT3, fT4 and TSH were $1.4-4.2 \mathrm{pg} / \mathrm{ml}, 0.8-2.2 \mathrm{ng} / \mathrm{dl}$ and 0.39-6.16 $\mathrm{mIU} / \mathrm{L}$ respectively. Patients with all thyroid hormones in normal range were considered as euthyroid. Patients with TSH level $>6.16 \mathrm{mIU} / \mathrm{L}$ and free T3 and free T4 in normal range were considered subclinical hypothyroid. Overt hypothyroidism was defined as TSH level $>6.16$ $\mathrm{mIU} / \mathrm{L}$ and free T3 and T4 lower than normal range. Subclinical hyperthyroidism was defined as $\mathrm{TSH}<0.39 \mathrm{mIU} / \mathrm{L}$ and normal free $\mathrm{T} 3$ and $\mathrm{T} 4$ level. Overt hyperthyroidism was defined as $\mathrm{TSH}<0.39 \mathrm{mIU} / \mathrm{L}$ and free $\mathrm{T} 3$ and $\mathrm{T} 4$ higher than normal range. The data was analyzed using SPSS version 20 .

Continuous variables were expressed as mean $\pm S D$ values and categorical variables as number (percentage). One way ANOVA test and Kruskal-wallis test was applied for continuous variables and chi-square test for categorical variables at $95 \%$ confidence interval. A p value < 0.05 was considered statistically significant.

\section{Results}

The mean age of study patients was $25.7 \pm 6.8$ years. Among the study patients, the most common menstrual disorder observed was irregular cycle $(72.5 \%, \mathrm{n}=169)$ followed by amenorrhea $(21.9 \%, \mathrm{n}=51)$ and menorrhagia $(5.6 \%, n=13)$. Most of the patients were in the age group $15-24$ years $(51.1 \%, n=119)$, followed 
by $25-34$ years $(36.1 \%, \mathrm{n}=84)$ and $35-45$ years $(12.9 \%, \mathrm{n}=30)$. Mean level of free T3 and T4 was $2.91 \pm 1.05 \mathrm{pg} / \mathrm{ml}, \quad 1.42 \pm 0.57 \mathrm{ng} / \mathrm{dl}$ respectively. Median TSH was $2.0 \mathrm{mIU} / \mathrm{L}$ (1.04.0). Level of thyroid hormones according to type of menstrual disorder is shown in table 1 . Significant difference in free T3 $(\mathrm{p}=0.026)$ and TSH level $(p=0.012)$ was observed among various menstrual disorders.

Among the study patients, $74.2 \%(\mathrm{n}=173)$ were euthyroid and $25.8 \%(\mathrm{n}=60)$ presented some kind of thyroid dysfunction. Most common thyroid dysfunction was subclinical hypothyroidism (14.2\%, $\mathrm{n}=33)$ followed by subclinical hyperthyroidism $(6.9 \%, \mathrm{n}=16)$, overt hyperthyroidism (3\%, $\mathrm{n}=7)$ and overt hypothyroidism (1.7\%, $\mathrm{n}=4)$. Thyroid dysfunction according to type of menstrual disorder and age range is shown in table 2. No significant difference in thyroid dysfunction was observed among different types of menstrual disorders, and among age subgroups.

\section{Discussion}

In the present study we observed that irregular cycle was the commonest menstrual disorders in women attending the thyroid laboratory, and much of the patients were of age group 15-24 years. However, in another study among dysfunctional uterine bleeding patients, most of the patients were in age group of 35-45 years (54\%), followed by $25-34$ years $(28 \%)$ [8]. In a study by Pahwa et al. among 100 dysfunctional uterine bleeding patients, the commonest menstrual complaint was menorrhagia constituting $50 \%$ followed by polymenorrhoea (19\%), menometrorrhagia (18\%), metropathia haemorrhagica $(7 \%)$ and $6 \%$ had irregular bleeding with uncertain pattern [9]. In a study among Nepalese adolescent girls menstrual disorders were found to be the second most common (23.80\%) gynecological problem [10].

In the present study, thyroid dysfunction was seen in $25.8 \%$ women with menstrual disorders, and women with menorrhagia have higher TSH level and lower free T3 level than women with other menstrual disorders. Higher level of TSH and lower free T3 observed in menorrhagia than in other menstrual disorders may be due to smaller number of women with menorrhagia in the present study that had poor thyroid function. The major thyroid dysfunction was subclinical hypothyroidism followed by subclinical hyperthyroidism, overt hyperthyroidism and overt hypothyroidism. Previous studies among women with menstrual disorders have reported thyroid dysfunction in varying rate among different population $[8,9]$. In a study among dysfunctional uterine bleeding patients, Sharma et al. reported hypothyroidism and hyperthyroidism in $22 \%$ and $14 \%$ patients respectively [8]. In study among 100 dysfunctional uterine bleeding patients by Pahwa et al. 22 were found to be hypothyroid, 2 hyperthyroid and the rest of the patients were euthyroid [9]. Previous studies among Nepalese population have also found thyroid dysfunction in large part of study population [4, 7].

Table 1. Thyroid hormones level according to menstrual disorders

\begin{tabular}{lccccc}
\hline Hormones & $\begin{array}{c}\text { Total, } \\
\mathbf{n}=\mathbf{2 3 3}\end{array}$ & $\begin{array}{c}\text { Irregular cycle, } \\
\mathbf{n}=169\end{array}$ & $\begin{array}{c}\text { Amenorrhea, } \\
\mathbf{n}=51\end{array}$ & $\begin{array}{c}\text { Menorrhagia, } \\
\mathbf{n}=13\end{array}$ & P value \\
\hline Free T3 $(\mathbf{p g} / \mathrm{ml})$ & $2.91 \pm 1.05$ & $2.88 \pm 0.89$ & $3.16 \pm 1.45$ & $2.31 \pm 0.86$ & 0.026 \\
Free T4 (ng/dl) & $1.42 \pm 0.57$ & $1.41 \pm 0.54$ & $1.55 \pm 0.67$ & $1.15 \pm 0.38$ & 0.062 \\
TSH (mIU/L) & $2.0(1.0-4.0)$ & $2.0(1.0-3.0)$ & $2.0(1.0-4.0)$ & $5.0(2.5-6.0)$ & 0.012 \\
\hline
\end{tabular}

Thyroid hormone levels are expressed as mean \pm SD except for TSH which is expressed as median (IQR). P value was calculated using one way ANOVA and Kruskal wallis test at $95 \%$ confidence interval.

Table 2. Thyroid function status according to menstrual disorders and age range

\begin{tabular}{|c|c|c|c|c|c|c|c|c|c|}
\hline Thyroid status & $\begin{array}{l}\text { Total, } \\
\mathrm{n}=233\end{array}$ & $\begin{array}{c}\text { Irregular } \\
\text { cycle, } \\
n=169\end{array}$ & $\begin{array}{c}\text { Amenorrhea, } \\
n=51\end{array}$ & $\begin{array}{c}\text { Menorrhagia, } \\
n=13\end{array}$ & $\begin{array}{c}\mathrm{P} \\
\text { value }\end{array}$ & $\begin{array}{l}15-24 \\
\text { years, } \\
n=119\end{array}$ & $\begin{array}{l}25-34 \\
\text { years, } \\
n=84\end{array}$ & $\begin{array}{l}35-45 \\
\text { years, } \\
n=30\end{array}$ & $\begin{array}{c}P \\
\text { value }\end{array}$ \\
\hline Euthyroid & $\begin{array}{c}173 \\
(74.2 \%)\end{array}$ & $\begin{array}{c}127 \\
(54.5 \%)\end{array}$ & $\begin{array}{c}38 \\
(16.3 \%)\end{array}$ & $\begin{array}{c}8 \\
(3.4 \%)\end{array}$ & 0.557 & $\begin{array}{c}92 \\
(39.5 \%)\end{array}$ & $\begin{array}{c}61 \\
(26.2 \%)\end{array}$ & $\begin{array}{c}20 \\
(8.6 \%)\end{array}$ & 0.449 \\
\hline $\begin{array}{l}\text { Subclinical } \\
\text { hypothyroidism }\end{array}$ & $\begin{array}{c}33 \\
(14.2 \%)\end{array}$ & $\begin{array}{c}20 \\
(8.6 \%)\end{array}$ & $\begin{array}{c}9 \\
(3.9 \%)\end{array}$ & $\begin{array}{c}4 \\
(1.7 \%)\end{array}$ & 0.122 & $\begin{array}{c}11 \\
(4.7 \%)\end{array}$ & $\begin{array}{c}16 \\
(6.9 \%)\end{array}$ & $\begin{array}{c}6 \\
(2.6 \%)\end{array}$ & 0.088 \\
\hline $\begin{array}{l}\text { Overt } \\
\text { hypothyroidism }\end{array}$ & $\begin{array}{c}4 \\
(1.7 \%)\end{array}$ & $\begin{array}{c}3 \\
(1.3 \%)\end{array}$ & 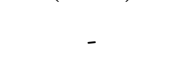 & $\begin{array}{c}1 \\
(0.43 \%)\end{array}$ & 0.162 & $\begin{array}{c}1 \\
(0.43 \%)\end{array}$ & $\begin{array}{c}1 \\
(0.43 \%)\end{array}$ & $\begin{array}{c}2 \\
(0.86 \%)\end{array}$ & 0.081 \\
\hline $\begin{array}{l}\text { Subclinical } \\
\text { hyperthyroidism }\end{array}$ & $\begin{array}{c}16 \\
(6.9 \%)\end{array}$ & $\begin{array}{c}15 \\
(6.4 \%)\end{array}$ & $\begin{array}{c}1 \\
(0.43 \%)\end{array}$ & - & 0.139 & $\begin{array}{c}10 \\
(4.3 \%)\end{array}$ & $\begin{array}{c}4 \\
(1.7 \%)\end{array}$ & $\begin{array}{c}2 \\
(0.86 \%)\end{array}$ & 0.6 \\
\hline $\begin{array}{l}\text { Overt } \\
\text { hyperthyroidism }\end{array}$ & $\begin{array}{c}7 \\
(3 \%) \\
\end{array}$ & $\begin{array}{c}4 \\
(1.7 \%) \\
\end{array}$ & $\begin{array}{c}3 \\
(1.3 \%) \\
\end{array}$ & - & 0.352 & $\begin{array}{c}5 \\
(2.1 \%) \\
\end{array}$ & $\begin{array}{c}2 \\
(0.86 \%)\end{array}$ & - & 0.443 \\
\hline
\end{tabular}


Thyroid dysfunction has been found to be associated with menstrual disturbances, however there are findings showing both high and low frequency of menstrual disorders in thyroid dysfunction [11]. Thyroid hormones affect menstrual cycle and both hyperthyroidism and hypothyroidism may result in menstrual disturbances [12]. Thyroid hormones play an important role in normal reproductive function both through direct effects on the ovaries and indirectly by interacting with sex hormone binding proteins. Thyroid dysfunction can lead to (reversible) menstrual irregularities and infertility. Treating thyroid dysfunction can reverse menstrual abnormalities and thus improve fertility [6].

\section{Conclusion}

The present study finds high rate of thyroid dysfunction especially subclinical hypothyroidism among Nepalese women with menstrual disorders. Thus it may be beneficial to screen menstrual disorder patients for thyroid dysfunction especially to rule out thyroid disorder as a potential etiological agent for menstrual disturbance. The study has however several limitations. First the sample size was small, so the finding may need to be verified in larger population. Since the study was cross-sectional no cause and effect relationship between menstrual disorders and thyroid dysfunction could be drawn. A number of other potential factors like thyroid autoimmunity and iodine deficiency or excess condition in study population may also be responsible for the thyroid disorder in the study patients since such components were not studied.

\section{Conflict of Interest}

None declared

\section{REFERENCES}

1. Abid M, Hashmi AA, Malik B, Haroon S, Faridi N, Edhi MM, et al. Clinical pattern and spectrum of endometrial pathologies in patients with abnormal uterine bleeding in Pakistan: need to adopt a more conservative approach to treatment. BMC Womens Health. 2014; 14:132.

http://dx.doi.org/10.1186/s12905014-0132-7

2. Harlow SD, Campbell OM. Epidemiology of menstrual disorders in developing countries: a systematic review. BJOG. 2004;111(1):6-16. http://dx.doi.org/10.1111/j.14710528.2004.00012.x

3. Unnikrishnan AG, Menon UV. Thyroid disorders in India: An epidemiological perspective. Indian J Endocrinol Metab. 2011;15(Suppl 2):S78-81.

http://dx.doi.org/10.4103/22308210.83329

4. Khatiwada S, Kc R, Sah SK, Khan SA, Chaudhari RK, Baral N, et al. Thyroid Dysfunction and Associated
Risk Factors among Nepalese Diabetes Mellitus Patients. Int J Endocrinol. 2015;2015:570198. http://dx.doi.org/10.1155/2015/570 198

5. Binita G, Suprava P, Mainak C, Koner BC, Alpana S. Correlation of prolactin and thyroid hormone concentration with menstrual patterns in infertile women. J Reprod Infertil. 2009;10(3):207-12.

6. Poppe K, Velkeniers B, Glinoer D. Thyroid disease and female reproduction. Clin Endocrinol (Oxf). 2007;66(3):309-21. http://dx.doi.org/10.1111/j.13652265.2007.02752.x

7. Khatiwada S, Kc R, Gautam S, Lamsal M, Baral N. Thyroid dysfunction and dyslipidemia in chronic kidney disease patients. BMC Endocr Disord. 2015;15:65. http://dx.doi.org/10.1186/s12902015-0063-9

8. Sharma N, Sharma A. Thyroid Profile In Menstrual Disorders. JK Science, 2012;14(1):14-17.
9. Pahwa S, Gupta S, Kaur J. Thyroid Dysfunction in Dysfunctional Uterine Bleeding. JARBS. 2013;5(1):78-83.

10. Karki C, Shrestha N, Rayamajhi R. Gynecological disorders of adolescent girls at Kathmandu Medical College Teaching Hospital. Nepal Journal Of Obstetrics And Gynaecology. 2014;3(2), 44-47. http://dx.doi.org/10.3126/njog.v3i2. 10831

11. Kakuno Y, Amino N, Kanoh M, Kawai M, Fujiwara M, Kimura M, et al. Menstrual disturbances in various thyroid diseases. Endocr J. 2010;57(12):1017-22. http://dx.doi.org/10.1507/endocrj.K $10 \mathrm{E}-216$

12. Koutras DA. Disturbances of menstruation in thyroid disease. Ann N Y Acad Sci. 1997;816:280-4. http://dx.doi.org/10.1111/j.17496632.1997.tb52152.x. 